\title{
„ČISTO VSEENO JE, ALI JE PLESALEC NA VOZIČKU ALI NE, SAJ USTVARJAM UMETNOST« Intervju $z$ učiteljem inkluzivne plesne skupine
o učenju plesa na invalidskem vozičku
}

Douglas Scott je plesalec, koreograf, pedagog in umetniški vodja, ki že več kot 25 let živi in dela v Atlantiv Georgii. Dolga leta je plesal s plesno skupino Ruth Mitchell ter hkrati delal kot plesni pedagog in koreograf. Leta 1991 je ustanovil inkluzivno plesno skupino, ki se danes imenuje Full Radius Dance in je ena redkih profesionalnih plesnih skupin te vrste v ZDA. Z inkluzivnim plesom, ki se takrat še ni imenoval tako, se je srečal leta 1990, ko je bil kot plesni učitelj povabljen na plesne delavnice za marginalne skupine (zaporniki, osebe z invalidnostjo, socialno izključeni ...). Takrat ni bilo mentorjev ali plesnih učiteljev, ki bi mu lahko svetovali o delu s plesalci na invalidskih vozičkih ali s posebnimi potrebami, in se je tako učil hkrati, ko je delal z njimi. Ustvaril je številne avtorske projekte in postavil na oder celovečerne plesne programe s svojo skupino. Prepoznaven je po odlični tehniki in inovativnem slogu. Douglas Scott je prejemnik številnih ameriških nagrad, zadnja je iz leta 2014, Governor's Award for Arts \& Humanities v državi Georgia.

Kakšno predstavo imajo ljudje o tvojem delu, ko rečeš, da si plesni pedagog in da učiš plesalce na invalidskih vozičkih ter delaš z njimi?

Mislijo, da sem terapevt, plesni terapevt, in pomagam ljudem na invalidskem vozičku. To ni moje delo, nikoli nisem študiral terapije. Sem plesalec in pedagog in od svojih plesalcev pričakujem veliko dela in piljenja tehnike.

\section{Ali se pristop $\mathrm{k}$ poučevanju plesalcev $\mathrm{z}$ invalidnostjo in neinvalidov razlikuje?}

Postal sem boljši učitelj, odkar delam s plesalci na invalidskih vozičkih. Proces je enak, ne delam nobenih razlik, vendar se na splošno bolj posvečam telesu in gibu plesalca. Začel sem poučevati individualno in šele potem skupinsko. Spoštujem vsakega plesalca in sledim razvoju giba in zmožnostim. Lahko je pokazati vajo pri baletu ali korake in plesalci sledijo, drugače pa je spoznati gibe vsakega plesalca in jih razvijati. To je moj cilj. Izoblikoval sem metode, da lahko vsi sledijo mojim vajam, zahvala gre plesalcem z invalidnostjo. 
Kako poteka proces od zamisli koreografije do postavitve plesa na odru? Si pri tem posebno pozoren na plesalce na vozičkih, da so vidni, v ospredju ...?

Po navadi imam zamisel, lahko denimo dobim idejo ali navdih iz fotografije in jo želim razviti prek giba. Včasih imam zamisel $\mathrm{v}$ glavi nekaj let, preden jo razvijem, prenesem na plesalce in postavim na oder. Odvisno je od navdiha. Čisto vseeno je, ali je plesalec na vozičku ali ne, saj ustvarjam umetnost. Ta umetnost je zame ples. Zelo je pomembno, da plesalci razumejo mojo idejo, da raziskujejo ter ji dodajo svojo interpretacijo in vrednost. To je plesni proces, ki ga želim od plesalcev. Na odru se pozna, ali plesalec dejansko razume celotno koreografijo in jo doživlja. Občinstvo to vidi.

Ko ustvarjaš novo delo, imaš torej v mislih občinstvo. Kaj si želiš, da ljudje vidijo, ko gredo na predstave Full Radius Dancea?

Veliko razmišljam o publiki in kako bo ta videla moje delo. Želim ustvarjati dostopne plesne koreografije, nisem konceptualni ustvarjalec. Želim, da publika razume, kaj se dogaja na odru. Nočem navduševati ljudi zaradi tega, ker imam inkluzivno plesno skupino, temveč želim pokazati ples, ki bo navdušil in se dotaknil občinstva. Predvsem z zadnjimi koreografijami raziskujem, kako se odziva publika, kaj ljudje doživijo, ko gledajo predstavo, kako se čustveno odzivajo na ples. Zame je velik kompliment, ko pride nekdo po predstavi in mi pove, da ni videl plesalcev na vozičkih, temveč ples - umetnost.

Plesalci morajo prestati avdicijo, da postanejo člani plesnega ansambla. Kaj je pomembno, tehnika, improvizacija, energija?

Vse našteto. Tehnika je zelo pomembna, ker menim, da lahko začneš improvizirati, ko si dobro tehnično podkovan. Treningov je veliko, potem so nastopi, zato tako tehnika kot fizična kondicija pripomoreta k dobri avdiciji. Pritegnejo pogumni plesalci, ki se ne bojijo pristopiti k plesalcu na invalidskem vozičku in ki so pripravljeni na akrobacijo. Improvizacija je pomembna, prav tako želja po raziskovanju lastnega giba. Vsega se ne opazi na eni sami avdiciji, ampak dovolj je, da vidim, ali je plesalec primeren za skupino. Rad presegam meje in spreminjam, kar se zdi nespremenljivo. Plesalce postavim pred izziv, da najdejo nov gib in ne ostanejo na območju udobja.

V ZDA je ustaljena praksa, da osnovne in srednje šole povabijo različne plesne in gledališke skupine, da predstavijo svoje delo. Predstave izobražujejo, širijo obzorja, rušijo predsodke ... S skupino Full Radius Dance nastopate v šolah, vendar tudi v domovih za ostarele in različnih društvih za aktivno življenje.

To je stalna praksa v ZDA in dobimo veliko vabil za nastope $\mathrm{v}$ šolah. Trenutno nastopamo s predstavo Let's Get Physics Y'all, ki sem jo koreografiral s pomočjo Inštituta za 
tehnologijo (Georgia Institute of Technology). Predstava na zanimiv način prikaže osnove fizike in hkrati, prek plesa, kako pomembno je ekipno delo. Mladi tako na zabaven način spoznajo fiziko in ples. Plesalce na invalidskih vozičkih vidijo z drugega zornega kota, kot ljudi, ki so sposobni narediti veliko stvari.

V centrih za starejše, za ljudi z Alzheimerjevo boleznijo in podobno izvajamo plesne delavnice, prirejene za njih. Včasih jih povabimo v naš plesni studio in pripravimo plesno delavnico, jim pokažemo naš proces dela, delno koreografijo. Mislim, da je pomembno vključevati celotno skupnost v Atlanti. Na splošno rad delam s starejšo populacijo.

V ZDA so že dolgo od tega v izobraževalno politiko umestili tudi področje umetniških dejavnosti in invalidnosti. Kako vidiš razvoj inkluzivnega plesa danes v Ameriki? Je veliko povezovanja med skupinami?

Če sem odkrit, se v zadnjih 20 letih ni veliko spremenilo, niti na bolje niti na slabše. V ZDA obstaja zelo malo profesionalnih plesnih ansamblov inkluzivnega plesa. Poleg moje skupine samo še dve, v San Franciscu in Ohiu. Mislim, da ste v Evropi v zadnjih letih napredovali zelo hitro in ste bolj odprti za novosti. Mogoče ni veliko profesionalnih skupin, vendar je veliko več možnosti in sodelovanja. V Atlanti je mogoče še nekaj ljudi, ki kot plesni učitelji delajo z ljudmi s posebnimi potrebami in slepimi, ampak samo kot prostočasna dejavnost. Obstajajo skupine, ki se ukvarjajo z osebami z invalidnostjo, ampak se raven znanja in kakovost poučevanja ne izboljšujeta. Nimamo izmenjave učiteljev ali plesnih delavnic, mogoče so težava velike razdalje, ampak mislim, da ni interesa, potrebe pa so.

Res je, kot si omenil, inkluzivni ples v Evropi postaja močnejši, je opazen. Vse več je skupin, ki se ukvarjajo $\mathrm{z}$ različnimi slogi plesa in vključujejo osebe $\mathrm{z}$ invalidnostjo. Ples je zelo priljubljen v Sloveniji, tudi inkluzivni ples se počasi prebuja. Ali slediš skupinam v Evropi, zaradi trendov, mogoče navdiha?

Sledim le nekaterim skupinam, kot sta denimo CandoCo iz Velike Britanije in Scottish Dance Theatre. Vidim, da je v Evropi zelo močan Wheelchair Ballroom Dancing, kar tukaj praktično ne obstaja, in vabimo veliko evropskih učiteljev na plesne seminarje. Na tem področju bi se želel naučiti veliko več, ker se mi zdi čudovito gledati te plesne pare. Včasih mi je navdih plesni video ali predstava, ki si jo ogledam, ampak jo potem prestrukturiram v glavi.

Umetniški vodja si že toliko let in še vedno je veliko idej, ki jih želiš uresničiti in postaviti na oder. Ali razmišljaš o predaji taktirke in upokojitvi?

Preveč sem sebičen, da bi opustil to delo. Resnično me zanima ples, celoten proces ustvarjanja nove koreografije, vsak plesalec posebej in tudi kot plesni pedagog sem vsak 
dan postavljen pred izziv. Obožujem svoje delo, in čeprav bom predal poučevanje mladim plesalcem in učiteljem, sam ne bom nehal ustvarjati.

Pogovarjala se je Monika Požek. 